\title{
Spatial and Temporal Variation in Brackish Wetland Seedbanks: Implications for Wetland Restoration Following Phragmites Control
}

\author{
Eric L. G. Hazelton ${ }^{1} \cdot$ Rebekah Downard $^{1}$ • Karin M. Kettenring ${ }^{1}$ • \\ Melissa K. McCormick ${ }^{2}$ Dennis F. Whigham ${ }^{2}$
}

Received: 23 September 2016 / Revised: 9 June 2017 / Accepted: 29 June 2017 /Published online: 25 September 2017

(C) The Author(s) 2017, corrected publication 2019

\begin{abstract}
Chesapeake Bay tidal wetlands are experiencing a broad-scale, aggressive invasion by the non-native, clonal grass Phragmites australis. The grass is often managed with herbicides in efforts to restore native plant communities and wildlife habitat. Management efforts, however, can act as a disturbance, resulting in increased light availability, potentially fostering reinvasion from soil seedbanks. If native vegetation establishes quickly from seedbanks, the site should have greater resiliency against invasion, while disturbed sites where native plants do not rapidly establish may be rapidly colonized by $P$. australis. We surveyed the soil seedbank of three vegetation cover types in five Chesapeake Bay subestuaries: areas where $P$. australis had been removed, where $P$. australis was left intact, and with native, reference vegetation. We determined the total germination, the proportion of the seedbank that was attributable to invasive species, the richness, the functional diversity, and the overall composition of the seedbanks in each of the cover types (i.e., plots). After 2 years of herbicide treatment in the $P$. australis removal plots, vegetation cover type impacted the total germination or the proportion of invasive species in the seedbank. In contrast, we also found that seedbank functional composition in tidal brackish
\end{abstract}

Communicated by Nancy L. Jackson

Electronic supplementary material The online version of this article (https://doi.org/10.1007/s12237-017-0289-z) contains supplementary material, which is available to authorized users.

Eric L. G. Hazelton

eric@hazelton-ecological.com

1 Ecology Center and Department of Watershed Sciences, Utah State University, Logan, UT 84322, USA

2 Smithsonian Environmental Research Center, P.O. Box 28, Edgewater, MD 21037, USA wetlands was not influenced by vegetation cover type in most cases. Instead, plots within a subestuary had similar seedbank functional composition across the years and were composed of diverse functional groups. Based on these findings, we conclude that plant community recovery following $P$. australis removal is not seed-limited, and any lack of native vegetation recruitment is likely the result of yet-to-bedetermined abiotic factors. These diverse seedbanks could lead to resilient wetland communities that could resist invasions. However, due to the prevalence of undesirable species in the seedbank, passive revegetation following invasive plant removal may speed up their re-establishment. The need for active revegetation will need to be assessed on a case-bycase basis to ensure restoration goals are achieved.

Keywords Invasive plant removal · Seedbank · Estuary · Chesapeake Bay $\cdot$ Phragmites $\cdot$ Revegetation

\section{Introduction}

Biological invasions are an increasingly detrimental component of global change, and have the capacity to impact species diversity and a wide array of ecosystem functions and services (Mack et al. 2000). Wetlands can be especially vulnerable to invasions because they are often downstream of the sources of nutrients, disturbances, and propagules that contribute to invasions (Zedler and Kercher 2005). Tidal wetlands experience additional pressure from invasive species because they receive pollutants and propagules from both the estuaries and the upland watersheds to which they are connected (Leck 1989). Given the large cultural, economic, and ecological value of wetlands (Palmer 2009), mitigating the impacts of invasive species in these systems is critical to maintaining the functions and services they provide (D'Antonio and Meyerson 2002). 
Following invasive species removal, facilitating rapid recruitment of native species to recover ecosystem structure and function can result in a system that resembles the native reference state. Revegetation is often crucial to establishing plant associations that are resilient and resistant to future or recurring invasions (Kettenring and Reinhardt Adams 2011; Palmer 2009). However, active revegetation, the practice of seeding or planting target species, can be prohibitively expensive (Hallinger and Shisler 2009). Rather than take on the expense, many managers instead follow more passive restoration methods that rely on existing seedbanks. In addition to being less costly, passive revegetation from the seedbank is often preferred, because it fosters the reestablishment of local species composition and genetic stock (Mitsch and Wilson 1996; William and Jorgenson 2003; Van der Valk and Pederson 1989).

Passive revegetation is particularly beneficial in tidal systems (Leck 2003; Huiskes et al. 1995; reviewed in Bakker et al. 1996), where water is the predominant vector for propagule transport (Neff et al. 2009), and tidal mixing and sorting can contribute to diverse species assemblages (Leck 1989). However, there are tradeoffs associated with passive revegetation between cost and efficacy. In order to establish a community that is resistant to future invasion, there must be enough propagules to establish viable populations, and they must be from a sufficiently functionally diverse set of species. The greater the functional diversity of revegetation in both growth form (woody, graminoid, forb) and life history (annual, perennial), the more resistant the recovered wetland is likely to be to invasion (Gioria et al. 2014; Byun et al. 2013; Peter and Burdick 2010), because functionally diverse species assemblages can more completely fill any niche that a future invader would exploit during colonization ("ecological redundancy" Suding 2011). When seedbanks are the primary mode of revegetation, the abundance and composition of the seedbank should be evaluated prior to management actions (Ficken and Menges 2013; Frieswyk and Zedler 2006). It is possible that there are insufficient seeds to reestablish desired vegetation (Le Peyre et al. 2005; Wetzel et al. 2001), and/or the proportion of undesirable or weedy species is too high to support revegetation goals.

In this study, we were particularly interested in the potential of Chesapeake Bay brackish tidal wetlands to form resistant (i.e., functionally diverse) native plant communities following the removal of invasive Phragmites australis (Poaceae, Trin. Ex. Steud; here forth Phragmites). Phragmites has lineages that are native to most regions of North America, but is a management concern due to the rapid range expansion of an invasive Eurasian lineage that forms dense monocultures in wetlands across the continent (Kettenring et al. 2012; Saltonstall 2002; Chambers et al. 1999). While Phragmites is actively managed across the USA, many management practitioners and land managers do not have the resources to actively revegetate on the scale of their management efforts, potentially leaving denuded wetland soils that are susceptible to new or repeat invasions (Hazelton et al. 2014).

Here, we evaluated the capacity of wetlands in five Chesapeake Bay subestuaries to recover from Phragmites invasion and its subsequent removal through passive revegetation. We sampled soil seedbanks in five subestuaries in three vegetation cover types where Phragmites was removed, Phragmites was left intact, and in native reference vegetation.

Our four primary questions were the following:

1. Do vegetation cover type and Phragmites removal impact the total seedbank density, species richness, and Phragmites emergence?

We hypothesized that the characteristics of the seedbank would vary across subestuaries based on differences in plant communities but within each subestuary, the seedbank would differ between sites with and without Phragmites.

2. Does vegetation cover type impact the species diversity of the seedbank?

We anticipated the seedbank composition to be richest in the native reference plots relative to the Phragmites-dominated plots within each subestuary.

3. Does removing invasive Phragmites by herbicide result in changes in the species composition of the seedbank?

We hypothesized that, within each subestuary, removal of Phragmites would result in increasing species richness of the seedbank following herbicide treatment.

4. Is there ample functional variation in the seedbank to form a resilient plant community following Phragmites removal?

\section{Methods}

\section{Sampling}

We sampled the seedbank in brackish tidal wetlands in five Chesapeake Bay subestuaries in Maryland USA: Nanjemoy, Patapsco, Severn, St Leonard, and Wicomico Rivers (Fig. 1) prior to herbicide treatment (2011) and twice following application of herbicides (2011-2013). In each subestuary, we sampled three vegetation cover types (i.e., plot: (1) Phragmites was removed by herbicide (Removal, "R"), (2) Phragmites was left intact (Control, 
Fig. 1 Map of sampling sites on the western shore of Chesapeake Bay

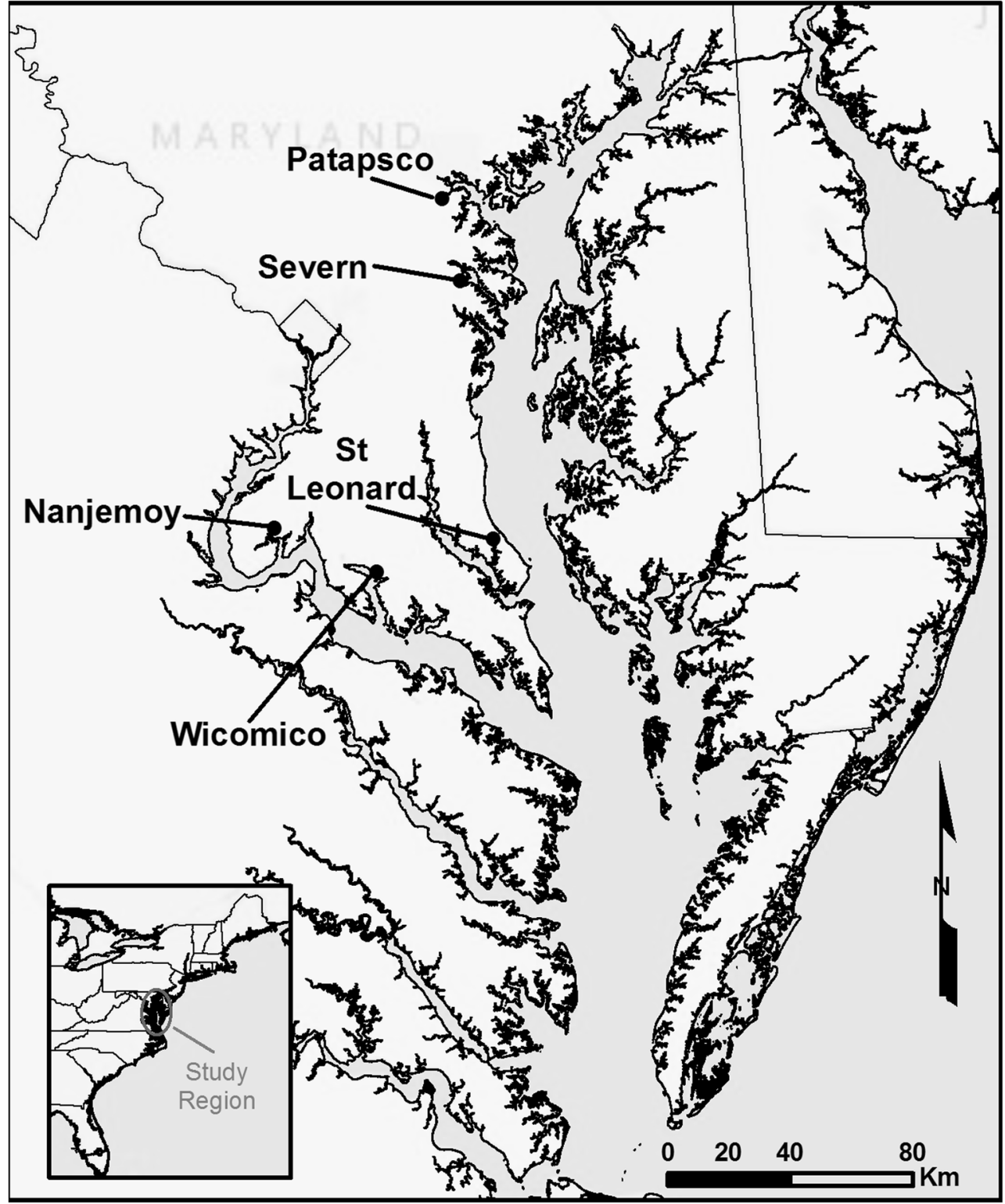

" $\mathrm{C}$ "), and (3) a native reference (Native, "N")). The herbicide removal plots were sprayed with a $3 \%$ glyphosate solution by helicopter in October 2011, with follow-up hand spraying in October 2012 (approximately 20-24 L per 0.4 ha along with a surfactant, Cide-Kick http://www. sepro.com/documents/CideKick_Label.pdf, and a marking dye Hi-Light http://bettervm.basf.us/products/label-andmsds/, both according to label specifications). Seedbank samples consisted of five soil cores $(5.08 \mathrm{~cm}$ diameter by $3 \mathrm{~cm}$ deep) collected from five $1 \mathrm{~m}^{2}$ quadrats (homogenized within each quadrat) along three permanent transects within each plot $(N=15$ per plot). Post-herbicide samples from 2012 to 2013 were collected in permanent quadrats, while 2011 pre-herbicide treatment samples were collected randomly along transects.

\section{Site Descriptions}

The Nanjemoy River is a tributary of the Potomac River in southern Maryland (Fig. 1). The watershed is predominately forested, which is associated with decreased Phragmites invasion in Chesapeake Bay (King et al. 2007; Sciance et al. 2016). The three cover types were adjacent to each other, though the Phragmites removal and control plots are separated by a short dike.

The Patapsco River is in the northern end of the Chesapeake Bay, and the watershed encompasses the city of Baltimore (Fig. 1). The watershed is largely developed (King et al.2007), and the subestuary is subject to urban runoff and associated water quality issues, including sewage spills (Sellner et al. 2001). Our sites were pocket wetlands on 
Marley Creek that form where streams enter the greater Patapsco subestuary. Each cover type was in a physically separate wetland but all were located within a $1.2 \mathrm{~km}$ stretch of river.

The Severn River watershed has been classified as developed (King et al. 2007). All three cover types were part of a single $0.5 \mathrm{~km}$ long wetland that is subdivided by a large dike and pier that separated the Phragmites removal and control types and a small tidal creek that separated the removal and reference cover types.

The St Leonard River is in a forested watershed (King et al. 2007) that drains into the Patuxent River (Fig. 1). This subestuary has less Phragmites cover than the others, though the invasion is spreading rapidly (MM and EH pers. obs.). Native wetlands in this system tend to have low species diversity and are largely comprised of Spartina alterniflora and Acnida cannabina (as described in McCormick and Sommes 1982).

The Wicomico, a tributary of the Potomac River in southwestern Maryland (Fig. 1), is the largest subestuary in the study. The watershed is predominately forested (King et al. 2007). The cover types were located along $0.75 \mathrm{~km}$ of a continuous fringing wetlandthat covers nearly $8 \mathrm{~km}$ of shoreline. The Wicomico site had more fetch (distance wind can travel over water) than any other in the study and comparatively had fewer patches of Phragmites in the subestuary.

\section{Sample Treatment}

Soil cores were collected in pre- (2011) and post-treatment (2012 and 2013) years in March while the vegetation was dormant. Cores were returned to the laboratory and kept in dark storage at $4{ }^{\circ} \mathrm{C}$ until September. In September, each core was visually checked to remove rhizomes, and the remaining material was spread thinly (approximately $2 \mathrm{~cm}$ deep) in aluminum tins (one per sample) on top of $200 \mathrm{~mL}$ of Sunshine Mix \#3 (http://www.sungro.com) in a glasshouse at Utah State University (41.757925 Lat, -111.813078 Lon; $1412 \mathrm{~m}$ elevation, Logan UT, USA). Blank samples containing only $500 \mathrm{~mL}$ of Sunshine Mix \#3 were randomly interspersed among the samples to record contamination from greenhouse weeds. Seedbank composition was determined by the emergence method (Baldwin et al. 2001; Poiani and Johnson 1988) under ambient greenhouse light with supplemental light from $1000 \mathrm{w}$ high-pressure sodium lamps (approximately $650 \mu \mathrm{mol} \mathrm{m} / \mathrm{s}$ ) to maintain a $16 / 8 \mathrm{~h}$ light/dark cycle. Samples were drip irrigated three times per day to maintain moist conditions with $400 \mathrm{~mL}$ of a nutrient solution (Peter's Excel 21-5-20, formulated to yield $100 \mathrm{ppm} \mathrm{N}$; www.everris.com) per cycle. Samples were germinated on a $10 / 27^{\circ}$ diurnal temperature fluctuation for 6 months (when germination had slowed to $<1$ seedling per week) each year. Plants were destructively harvested as soon as they reached an identifiable size. Voucher specimens for each species were grown to flower for deposition in the Intermountain Herbarium at Utah State University. Some genera were grouped together because they did not flower during the course of the study (Typha spp., Cyperus spp., Carex spp.). The blank samples contained high densities of Oxalis sp. and the species were removed from all analyses. Eleocharis parvula was omitted from analyses since it was impossible to determine whether plants grew from seeds or remnant rhizomes due to its small rhizome size.

\section{Data Analysis}

To determine the impact of treatment plot $(\mathrm{C}, \mathrm{R}, \mathrm{N})$ on the total number of seeds that germinated, species richness, and number of germinated Phragmites seeds, we compared the means for each treatment within subestuaries (question 1). These analyses were conducted in JMP (SAS Institute www. JMP.com) as a one-way ANOVA comparing mean Phragmites germination, total number of seedlings of all species, and species richness across treatment plots, with quadrat as the unit of replication nested within plot. After evaluation of the distribution of the residuals, we determined that data transformations were not necessary to meet model assumptions of normality and homogeneity of variance. Since we did not have repeated sampling locations prior to spraying as in the two following years, the data are not suited for a time series and each year was analyzed individually.

Preliminary NMDS analyses determined that the differences in seedbanks between subestuaries were profound enough that including subestuary as a factor overshadowed the effect of treatment. Final multivariate and linear regression analyses were conducted separately for each subestuary and each is presented as a separate case study below.

To analyze community composition (questions 2 and 3), we conducted multivariate data analyses, including perMANOVA and nonparametric multidimensional scaling (NMDS), which can be particularly informative in seedbank studies (Gioria and Osborne 2009). Rare species in each subestuary (present in $<5 \%$ of samples) were omitted from the analysis for the subestuary where they were rare (rare species disproportionately impact ordinations, per Legendre and Legendre 2012). Subsequently, samples that did not contain any common species (all zeroes) were removed prior to NMDS and perMANOVA. Multivariate analyses were conducted in Primer® package (http://www.primer-e.com/).

We developed regression models to compare plant functional group composition between treatment plots (questions 3 and 4). Seedbank species were classified by (1) functional groups: graminoids, forbs (including ferns), and woody species; and (2) guild: native annual (NA), native perennial (NP), and introduced perennial (IP) (per Kettenring and Galatowitsch 2011); invasive annuals were removed from 
analysis as they were rare and skewed the interpretation of more common groups. The generalized linear mixed model we developed predicted total germination of plant functional groups and plant guilds within each sample as a function of the predictor variable plot $(\mathrm{C}, \mathrm{R}, \mathrm{N})$. Invasive annuals were rare (present in $<5 \%$ of samples) and removed from analysis, as they skewed the interpretation of more common guilds. Species that could not be determined as native or introduced (Typha spp., Acorus spp.) at the seedling stage were classified as introduced to give a conservative estimate of native diversity (classification according to USDA Plants Database (USDA-NRCS, 2015)). Unlike in the multivariate analyses, rare species were included in the regression analysis, while germination counts for each species or genus were relativized to per $\mathrm{m}^{2}$. Linear regression analysis was conducted in SAS using proc. GLIMMIX (treatment by guild; treatment by functional group; no fixed effects designated), specifying a negative binomial distribution to account for zero-skewed data (SAS Institute).

\section{Results}

\section{Community Response}

Across all subestuaries, we generally found a similar pattern in the community composition of the seedbank. The seed banks in most cases were not distinct by plot types $(\mathrm{C}, \mathrm{R}, \mathrm{N})$, and instead showed a moderate amount of overlap across plot types and years (as indicated by somewhat overlapping ellipses in Fig. 2). Exceptions to these patterns did occur, however, as we will describe below in our detailed discussion of the individual subestuary responses (Table 1).

In the Nanjemoy, prior to herbicide treatment (2011), the seedbank in the native reference wetland differed from the Phragmites removal and control plots, yet there was overlap in seedbank composition between all three plots (Table 2; Fig. 2). In 2012 and 2013, following herbicide treatments, the seedbank in the reference plot remained distinct, and there was little differentiation between the removal and control plots (Table 3; Fig. 2). Pairwise perMANOVA results showed that seedbanks in control and reference plots were marginally not significantly different ( $\alpha=0.05$ ) during 2011 , but were significantly different during subsequent years. Meanwhile, the intact control plot and the herbicide-treated removal plot initially differed significantly but converged following herbicide treatments. During all years of the study, seedbank composition was significantly different between reference wetlands and herbicide-treated plots (Table 2).

In 2011, the seedbanks of all three plots in the Patapsco subestuary differed from each other (Fig. 2), but the native reference plot was more similar to the Phragmites removal plot than either were to the Phragmites control plot (Table 2;
Fig. 2). Following the first herbicide treatment, the seedbank of the Phragmites removal plot differed from the control and reference plot so much that there was no overlap between plots (Fig. 2). The native reference clustered with the Phragmites control plot (Table 2; Fig. 2). In the second year after herbicide application (2013), there was more overlap between all three treatments (Table 2; Fig. 2). All pairwise comparisons of seedbank composition between plots were significantly different in each of the 3 years (Table 3 ).

In the Severn River, the three plots clustered individually with minimal overlap, indicating different initial seedbank compositions (Fig. 2). Following the initial herbicide treatment, those differences became more pronounced (Fig. 2). By 2013, the plot from which Phragmites had been removed had a more distinct seedbank, as seen in the distance between clusters, from intact control and native reference plots (Fig. 2). The three plots were significantly different from each other in all pairwise comparisons over all 3 years (Table 3 ).

Prior to herbicide treatment, the native reference seedbank in the St Leonard samples was distinct from either of the two Phragmites dominated sites (removal and control) and exhibited a spatially uniform distribution of seeds within the plot, as seen in the tight NMDS plot clustering (Fig. 2). The control and herbicide-treated Phragmites plot seedbanks were similar, but neither were as spatially uniform as the native reference plot (Fig. 2). Following the first spraying treatment, the seedbank at the native reference plot remained distinct from the Phragmites plot. The Phragmites removal and control plot seedbanks remained similar, but not as evenly as prior to herbicide application (Fig. 2). By 2013, the Phragmites removal and control plots developed similar and homogeneous seedbanks (Fig. 2). The distinctness of the native reference plot, which moved farther from the Phragmites control and removal plots in each year, was validated by perMANOVA results, which showed that the reference wetland was significantly different from the Phragmites-removal wetland each year (Table 3).

The seedbanks of the plots in the Wicomico subestuary were similar prior to herbicide application, as indicated by the significant overlap in the NMDS plots (Fig. 2). Differences between Phragmites-removal and control treatments emerge by 2013, though there were still similarities between plots (Fig. 2). The reference plot was significantly different from control and removal plots in 2011, according to perMANOVA results, but there were no significant differences between plots during in subsequent years (Table 2).

\section{Functional Responses}

The functional composition of the seed banks generally reflected unique compositions of each subestuary, rather than distinct differences across years and plot types $(\mathrm{C}, \mathrm{N}, \mathrm{R}$; Fig. 3 ). Based on seedling emergence counts, seed quantity varies 
2011
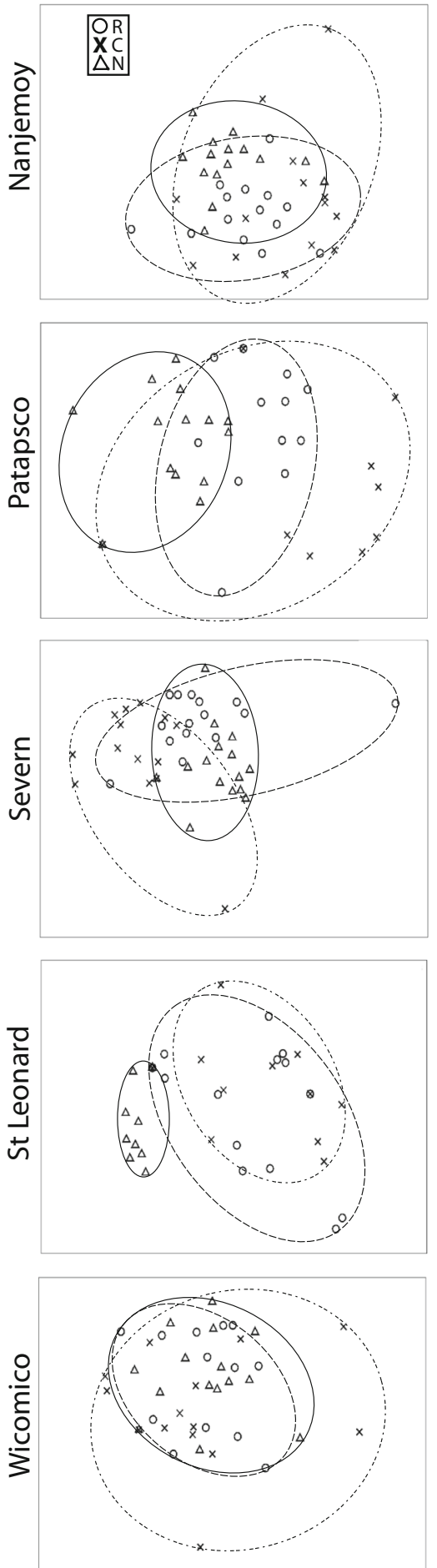

Fig. 2 Nonmetric multidimensional scaling (NMDS) graphs for seedbank composition in all five study wetlands, for each of the ]3 years. Year 1 (2011) is prior to herbicide treatment, while years 2 and 3 (2012-2013) are after continued herbicide application. As shown in the legend, circles are for " $\mathrm{R}$ ", the Phragmites removal plots (with long-

broadly across years in nearly all subestuaries. Nonetheless, some interesting year and plot type trends within a subestuary occurred and are discussed in greater detail below.
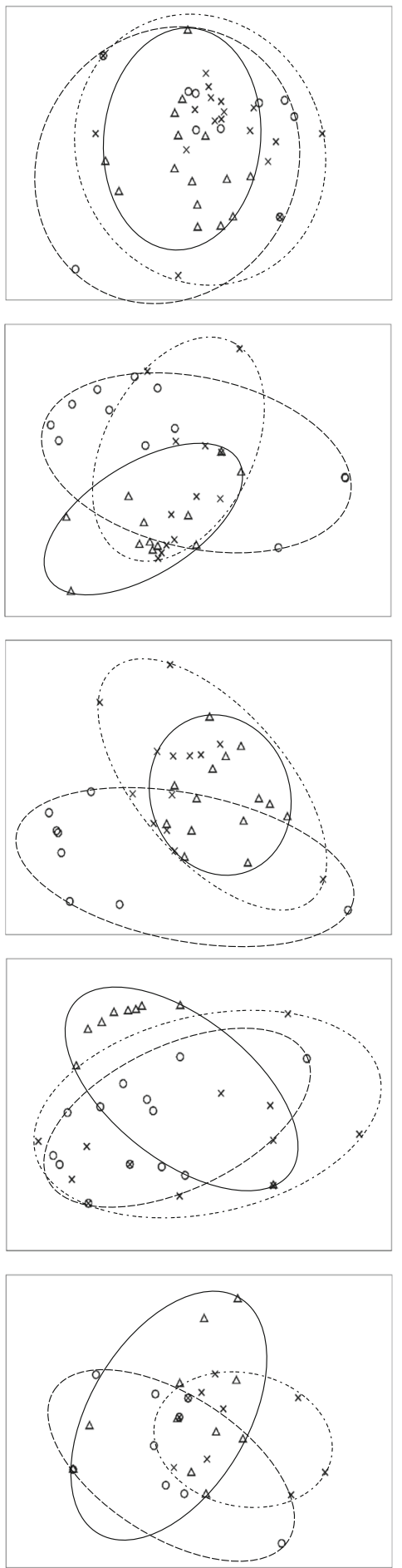

dashed line); $X$ indicates that the sample was in a " $\mathrm{C}$ " control plot with Phragmites left intact (short-dashed lines). The triangle symbol is for samples collected in the "N" native reference plot (solid lines). Details on the NMDS scores and perMANOVA can be found in Table 2

In the Nanjemoy, the functional vegetation types (forb, graminoid, and woody) showed similar compositional trends (no significant plot effects across years) in during all 3 years of 
Table 1 Phragmites germination responses. Results from a one-way ANOVA of treatment effect on total Phragmites emergence for all wetlands in all 3 years $(\alpha=0.05)$

Phragmites germination responses

\begin{tabular}{|c|c|c|c|c|c|c|}
\hline & \multicolumn{2}{|c|}{ Year 1} & \multicolumn{2}{|l|}{ Year 2} & \multicolumn{2}{|c|}{ Year 3} \\
\hline & $\mathrm{F}$ & $\mathrm{P}$ & $\mathrm{F}$ & $\mathrm{P}$ & $\mathrm{F}$ & $\mathrm{P}$ \\
\hline Nanjemoy & 1.75 & 0.1860 & 1.58 & 0.2178 & 1.57 & 0.2194 \\
\hline Patapsco & 6.47 & 0.0035 & 2.21 & 0.1226 & 0.31 & 0.7360 \\
\hline Severn & 4.65 & 0.0150 & 13.49 & $<0.0001$ & 5.57 & 0.0072 \\
\hline St Leonard & 11.70 & $<0.0001$ & 7.55 & 0.0015 & 2.94 & 0.0614 \\
\hline Wicomico & 3.14 & 0.0537 & 1.05 & 0.3589 & 1.00 & 0.3765 \\
\hline
\end{tabular}

the study: increasing germination over time, especially among forbs and graminoids (Fig. 3). The number of woody plant species seedlings were low in all years, however, and the number germinating decreased over time. There was no significant plot effect on the number of seedlings in the emergence of species in the functional groupings in any year (Fig. 3).

Prior to spraying in the Patapsco River, the seedlings that emerged in the functional groups were similar in the two Phragmites-dominated plots: forb seedlings were more prevalent than graminoids, which, in turn germinated in higher numbers compared to woody species. The native reference plot had fewer graminoids seedlings relative to forbs and woody vegetation. This overall pattern of emergence continued in 2012 (Fig. 3). Woody vegetation emergence was significantly higher in the reference plot in years 2011 and 2013, which was the only significant effect of plot on functional vegetation (Fig. 3). Within the native reference plot, woody plant germination was higher than graminoid, but not forbs in all 3 years. In all treatments, the germination of forbs was exceptionally high in 2013. Overall, graminoid germination was low in all three treatments for each year. In the removal and reference plots, the emergence of forbs increased by an order of magnitude between 2011 and

Table 2 Nonmetric multidimensional scaling (NMDS) and perMANOVA scores for species composition. All five study systems are represented for each year. The $\mathrm{P}(\mathrm{perm})$ value is indicating the presence of significant differences $(\alpha=0.05)$ in seedbank composition and
2012, while the number of forbs did not increase in the controls until 2013 (Fig. 3). Typha spp. and Pluchea odorata were the dominant forbs across all plots.

During 2011, the functional groups in the Severn River removal plot resembled the native reference more than the Phragmites control, in that both seedbanks were dominated by forbs. The reference plot initially had higher emergence of woody species and lower graminoid emergence than the two Phragmites dominated plots (Fig. 3). In years 2012 and 2013, forb germination in the control and reference plots was significantly greater than in the removal; during that period, the removal plot had significantly higher graminoid emergence (Figs. 3 and 4).

Examining the functional group diversity within seedbanks in the St Leonard River, plants that emerged from soils in the native reference plot was heavily dominated by forbs during the entire study. The most common forb in the reference seedbank was A. cannabina. In the reference plot, few graminoid and woody species emerged from the samples in all years, and the graminoid germination was significantly different than the other plots in each year (Fig. 3). In Phragmites removal and control plots, 2012 graminoid emergence was higher than forb emergence, a shift from other years.

In the initial, pre-spraying sampling of the Wicomico River Phragmites plot, the three plots showed very similar patterns in emergence between the functional groups. In all three plots over all 3 years, forbs dominated the seedbank, followed by graminoids, while woody vegetation was a minor component (Fig. 3). This pattern persists in 2012, with the exception of greater graminoid germination in the control plot, while the reference and removal plots remained similar to 2011. The only significant difference in functional vegetation between plots was between the control and removal plots in 2013. Despite being low relative to forb germination, there was greater graminoid emergence in the Wicomico than other

emergence between all three plot types (Control: Phragmites intact; Removal: Phragmites removed after year 1; Native: native reference plot) within each wetland for each year. The stress values are for the corresponding NMDS graphs in Fig. 1

perMANOVA and NMDS

\begin{tabular}{|c|c|c|c|c|c|c|c|c|c|}
\hline & \multicolumn{3}{|l|}{ Year 1} & \multicolumn{3}{|l|}{ Year 2} & \multicolumn{3}{|l|}{ Year 3} \\
\hline & Pseudo-F & $\mathrm{P}($ perm $)$ & Stress & Pseudo-F & $\mathrm{P}($ perm $)$ & Stress & Pseudo-F & $\mathrm{P}($ perm $)$ & Stress \\
\hline Nanjemoy & 3.89 & 0.001 & 0.19 & 2.32 & 0.002 & 0.17 & 1.82 & 0.023 & 0.17 \\
\hline Patapsco & 8.05 & 0.001 & 0.13 & 6.00 & 0.001 & 0.12 & 4.23 & 0.001 & 0.09 \\
\hline Severn & 7.74 & 0.001 & 0.13 & 9.79 & 0.001 & 0.11 & 6.53 & 0.001 & 0.10 \\
\hline St Leonard & 11.00 & 0.001 & 0.08 & 10.74 & 0.001 & 0.10 & 7.64 & 0.001 & 0.06 \\
\hline Wicomico & 2.03 & 0.013 & 0.20 & 0.51 & 0.912 & 0.10 & 1.30 & 0.193 & 0.08 \\
\hline
\end{tabular}


subestuaries. The graminoids were dominated by Schoenoplectus robustus, Schoenoplectus acutus, and Spartina cynosuroides.

\section{Guild Response}

The seedbank in each subestuary differed in the composition of species in guilds, and generally did not vary by year or cover type. Exceptions to this overall pattern are discussed in detail below. Even though the relative proportions of guilds in the seedbank were consistent within subestuaries (Fig. 4), the numbers of seeds representing each guild often varied by several orders of magnitude.

The Nanjemoy seedbank plant guild (native annual, native perennial, and introduced perennial) germination showed anecdotal variation between years. In the Phragmites control and removal plots, native annual emergence was greater than native perennial emergence in 2011, while they were equal in the native reference plot. In 2012, the Phragmites removal plot plant guild composition resembled the pre-treatment (2011)

Table 3 Pairwise perMANOVA scores for each treatment. The seedbank species composition for each wetland and year are presented in a pairwise manner to elucidate differences $(\alpha=0.05)$ between treatments within each wetland and year. Treatments are "C" control with Phragmites intact, "R" removal plots where herbicide was applied after year 1 , and "N" native reference plots

Pairwise perMANOVA for each treatment

\begin{tabular}{|c|c|c|c|c|c|c|}
\hline & \multicolumn{2}{|c|}{ Year 1} & \multicolumn{2}{|c|}{ Year 2} & \multicolumn{2}{|c|}{ Year 3} \\
\hline & $\mathrm{T}$ & $\mathrm{P}($ perm $)$ & $\mathrm{T}$ & $\mathrm{P}($ perm $)$ & $\mathrm{T}$ & $\mathrm{P}($ perm $)$ \\
\hline \multicolumn{7}{|c|}{ Nanjemoy } \\
\hline $\mathrm{C} \times \mathrm{N}$ & 1.40 & 0.069 & 1.65 & 0.001 & 1.48 & 0.025 \\
\hline $\mathrm{C} \times \mathrm{R}$ & 2.29 & 0.001 & 0.95 & 0.497 & 0.62 & 0.941 \\
\hline $\mathrm{N} \times \mathrm{R}$ & 2.15 & 0.001 & 1.83 & 0.001 & 1.69 & 0.003 \\
\hline \multicolumn{7}{|c|}{ Patapsco } \\
\hline $\mathrm{C} \times \mathrm{N}$ & 2.72 & 0.001 & 1.74 & 0.030 & 1.28 & 0.030 \\
\hline $\mathrm{C} \times \mathrm{R}$ & 2.02 & 0.001 & 2.38 & 0.001 & 2.38 & 0.001 \\
\hline $\mathrm{N} \times \mathrm{R}$ & 3.49 & 0.001 & 2.99 & 0.001 & 2.99 & 0.001 \\
\hline \multicolumn{7}{|l|}{ Severn } \\
\hline $\mathrm{C} \times \mathrm{N}$ & 2.33 & 0.001 & 2.48 & 0.001 & 1.55 & 0.022 \\
\hline $\mathrm{C} \times \mathrm{R}$ & 2.60 & 0.001 & 2.73 & 0.001 & 2.74 & 0.001 \\
\hline $\mathrm{N} \times \mathrm{R}$ & 3.37 & 0.001 & 4.17 & 0.001 & 3.32 & 0.001 \\
\hline \multicolumn{7}{|c|}{ St Leonard } \\
\hline $\mathrm{C} \times \mathrm{N}$ & 1.27 & 0.189 & 4.24 & 0.001 & 3.68 & 0.001 \\
\hline $\mathrm{C} \times \mathrm{R}$ & 3.93 & 0.001 & 1.71 & 0.018 & 1.14 & 0.252 \\
\hline $\mathrm{N} \times \mathrm{R}$ & 4.80 & 0.001 & 3.60 & 0.001 & 3.20 & 0.001 \\
\hline \multicolumn{7}{|c|}{ Wicomico } \\
\hline $\mathrm{C} \times \mathrm{N}$ & 1.45 & 0.024 & 0.86 & 0.654 & 1.18 & 0.210 \\
\hline $\mathrm{C} \times \mathrm{R}$ & 1.29 & 0.123 & 0.71 & 0.835 & 1.26 & 0.129 \\
\hline $\mathrm{N} \times \mathrm{R}$ & 1.49 & 0.026 & 0.51 & 0.944 & 0.97 & 0.467 \\
\hline
\end{tabular}

pattern, while in the control and reference plots native annual germination was marginally higher than native perennial and both exceeded germination of introduced perennials. The only significant difference in emergence between plots was in 2013, when the removal plot had significantly lower introduced perennial germination than the reference plot (Fig. 4).

Introduced perennial germination was the distinguishing feature of the functional guild analysis of the Patapsco subestuary. In 2011, introduced perennial species dominated the Phragmites removal plot. The native reference had higher germination of native perennials than any other guild, though introduced perennial germination was high as well (Fig. 4). In 2012, after spraying, the removal plot had similar plant guild responses in the control plot (Fig. 4). The control and reference plots both had high emergence of introduced perennial, which was significantly different from the removal plot in years 2012 and 2013. The removal had highest germination of native annuals in 2013, while the reference plot had a high germination rate of native perennials (Fig. 4). The introduced perennial guild increases paralleled the forbs pattern seen in the function analysis and was driven by the prevalence of Typha spp. The elevated presence of native perennials in the reference site was likely due to the relatively high germination of woody species Iva frutescens, Baccharis halmifolia, and Hibiscus moscheutos.

Prior to spraying in the Severn River, all three plots had high numbers of seeds germinating in the native perennial and introduced perennial guilds. Native annual emergence was significantly higher in removal and reference plots than the Phragmites control plot. In 2012, the number of plants that emerged in each of the guilds changed dramatically with the number of native annuals highest in the control plot, followed by the reference, while absent in the removal. All three plots had high to moderate numbers of introduced perennial species that germinated in 2013. The control and reference plots had significantly higher rates of native annual germination than the removal (Fig. 4). The prominence of introduced perennial in seedbank composition in all years and plots was driven by two species: Phragmites and Typha spp. The native annual guild, prevalent in alternating plots over the study, was largely comprised of $P$. odorata. The forb functional group was also likely dominated by $P$. odorata as well. The less common native perennial guild was comprised mostly of Spartina patens and Schoenoplectus robustus.

The dominance of A. cannabina in the St Leonard reference wetland was reflected in the species richness and plant guild assembly as well: native annuals were the most prevalent group. In all years, the control and removal seedbanks were significantly different and comprised primarily of introduced perennial and native perennial (Fig. 4). Common native perennial species in this wetland included Schoeplectus robustus and Eupatorium altissima. The control and removal plots both had 

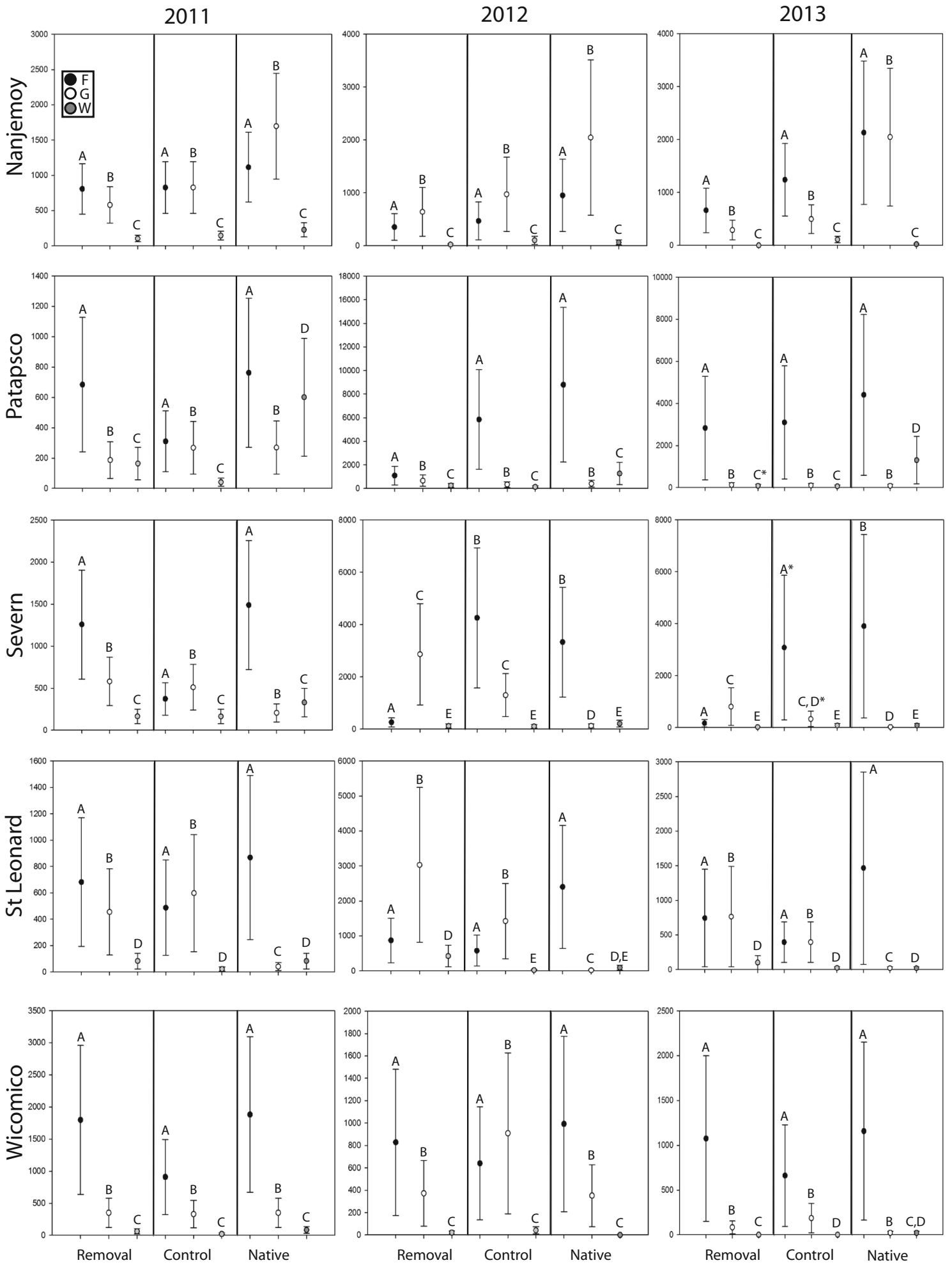

Fig. 3 Functional analysis of germination rates. The number of plants that germinated and emerged from the substate samples categoriezed as "F" forbs, "G" graminoids, and woody "W" are shown on the $Y$ axis and expressed as seedling counts per $\mathrm{m}^{2} \pm 1 \mathrm{se}$. All five surveyed wetlands are shown, with results for each of the 3 years. Year 1 is prior to herbicide application. Each sub-figure is divided by plot treatment: Removal where

Phragmites was treated with glyphosate after year 1, Control is an intact Phragmites monoculture and Native is the native reference plot. Letters above error bars indicate significant differences of each functional type between treatments $(\alpha=0.05)$ within a given year; they do not indicate differences between the functional types. Differences marked with an * are marginally non-significant $(\alpha=0.07)$ 



Fig. 4 Guild analysis of life history and native vs. invasive germination rates. All five study subestuaries are represented for each of the 3 years of the study. Year 1 (2011) is prior to herbicide treatment, while the "Removal" plots were sprayed in years 2012 and 2013. The Control is an intact Phragmites monoculture, and the Native is a native reference wetland. The $Y$ axis displays the emergence of seedlings expressed as

number of germinations per $\mathrm{m}^{2} \pm 1$ se. The significant letters represent the differences between treatments $(\alpha=0.05)$, bars marked with an * are marginally non-significant $(\alpha>0.05,<0.07)$. The three guilds are: "IP" invasive perennials, "NA" native annuals, and "NP" native perennials. Invasive annuals were not present in sufficient numbers to analyze 
increased emergence of both perennial guilds in years 2012 and 2013 (Fig. 4).

As with the functional types, in 2011, the Wicomico seedbanks had similar plant guild patterns across all plots (Fig. 4). The only change in 2012 was increased emergence of native perennial species from soils collected at the control plot. During 2013, the number of native annual species that germinated rebounded to 2011 levels. None of the guilds were significantly different between plots in any year (Fig. 4). Across all plots and years, the native perennial guild is a prominent component of the seedbank composition. The most prevalent forbs (the dominant functional group) in the Wicomico were the native annual species $P$. odorata and A. cannabina. Common native perennial species included the graminoids mentioned above, as well as the native species Lythrum lineare and Polygonum punctatum, and the introduced species Typha spp. and Polygonum hydropiperoides.

\section{Germination Results}

The number of Phragmites seeds that germinated from the seed bank was generally a small proportion of the total seeds in each seed bank, across plot types and years, regardless of subestuary (Fig. 5). The year-toyear variation in the total number of plants that emerged from the seedbanks was quite large and did not seem to generally vary in any discernable pattern (e.g., pre- vs. post-Phragmites removal) across subestuaries (Fig. 2). The within subestuary patterns in total seed germination seemed to reflect unique seed bank properties specific to the subestuaries, as described below.

Phragmites germination was a small fraction of the total germination in the Nanjemoy and only significantly different between the reference and the two Phragmites plots in 2011 and 2012 (Table 1; Fig. 5), while total germination of all species across functional types and guilds was highest in the reference plot in all years. Species richness was highest in the reference plot in years 2011 and 2013, but not in 2012 (2011 $6.7 \pm 0.58 ; 20122.7 \pm 0.54 ; 20134.6 \pm 0.41$; Fig. 6). Richness was higher in the control than the removal in years 2012 and 2013, and the latter plot did not seem to have an herbicide effect on richness (Fig. 6).

Germination of seeds from Patapsco River samples was significantly different between the plots in 2011 and 2012, but not 2013 (Table 4). The pattern of total emergence was driven by significantly higher germination from samples collected in the native reference plot (Fig. 5). Phragmites emergence was significantly lower in the reference plot than the Phragmites removal and control plots in 2011 (Fig. 5), and there were no significant differences in Phragmites germination in 2012 or 2013 (Table 1). Species richness was highest in the native reference plot, and all plots showed the lowest richness in $2013(N$ plot values $20114.1 \pm 0.42 ; 2012$ $4.5 \pm 0.63 ; 20132.9 \pm 0.47$; Fig. 6).

Severn River Phragmites germination was significantly higher in the removal plot in 2012 and 2013 and negligible in the reference plot in all years (Table 1). Total germination was significantly different between the plots in 2011 and 2013 , with the removal plot having the lowest emergence (Table 4; Fig. 5). Species richness was not significantly different in 2011, yet richness precipitously decreased in the removal plot in 2012 and 2013 ( $N$ plot values $20113.8 \pm 0.47 ; 2012$ $3.1 \pm 0.47$; $20133.1 \pm 0.38$; Fig. 6 ).

St. Leonard total emergence was not significantly different between plots in any of the 3 years (Table 4; Fig. 5). Phragmites germination was significantly lower in the native reference plot in all years (Table 1; Fig. 5). Species richness was lowest in the reference plot in all years, and highest in the removal plot after herbicide application ( $\mathrm{N}$ plot values $20111.6 \pm 0.5 ; 2012$ $1.2 \pm 0.54 ; 20131.1 \pm 0.41$; Fig. 6).

The total germination and Phragmites germination were both significantly different across plots in 2011 for the Wicomico River (Fig. 5), and Phragmites was a comparably minor component of the total seedbank composition relative to the other subestuaries. The total germination rate was lowest in the control plot in years 2011 and 2013, which also had the highest Phragmites emergence (Fig. 5). Species richness was not different between the plots $(N$ plot values 2011 $4.7 \pm 0.54 ; 20121.9 \pm 0.51 ; 20131.8 \pm 0.35$; Fig. 6 ), which was reflected in the guild analysis.

\section{Discussion}

We set out to answer four major research questions: (1). Do vegetation type and Phragmites removal impact the density of seedlings that emerge from the total seedbank density, the species' richness of plants that emerge from the seedbank, and the density of Phragmites seedlings that emerge from the seedbank? (2). Does vegetation cover type impact seedbank composition? (3). Does removing invasive Phragmites by herbicide impact the seedbank composition? (4). Since functional diversity could lead to a more resilient wetland, is there enough functional diversity in the seedbank to justify passive revegetation? We found that the species composition of the seedbank primarily differed among subestuaries, and likely reflected distinct subestuary and plot type characteristics, rather than the Phragmites removal treatments or aboveground vegetation composition. Below, we discuss potential factors that may be driving these surprising results, especially the highly variable seed bank compositions at the scale of individual subestuaries. Furthermore, we found that diverse seed banks exist 

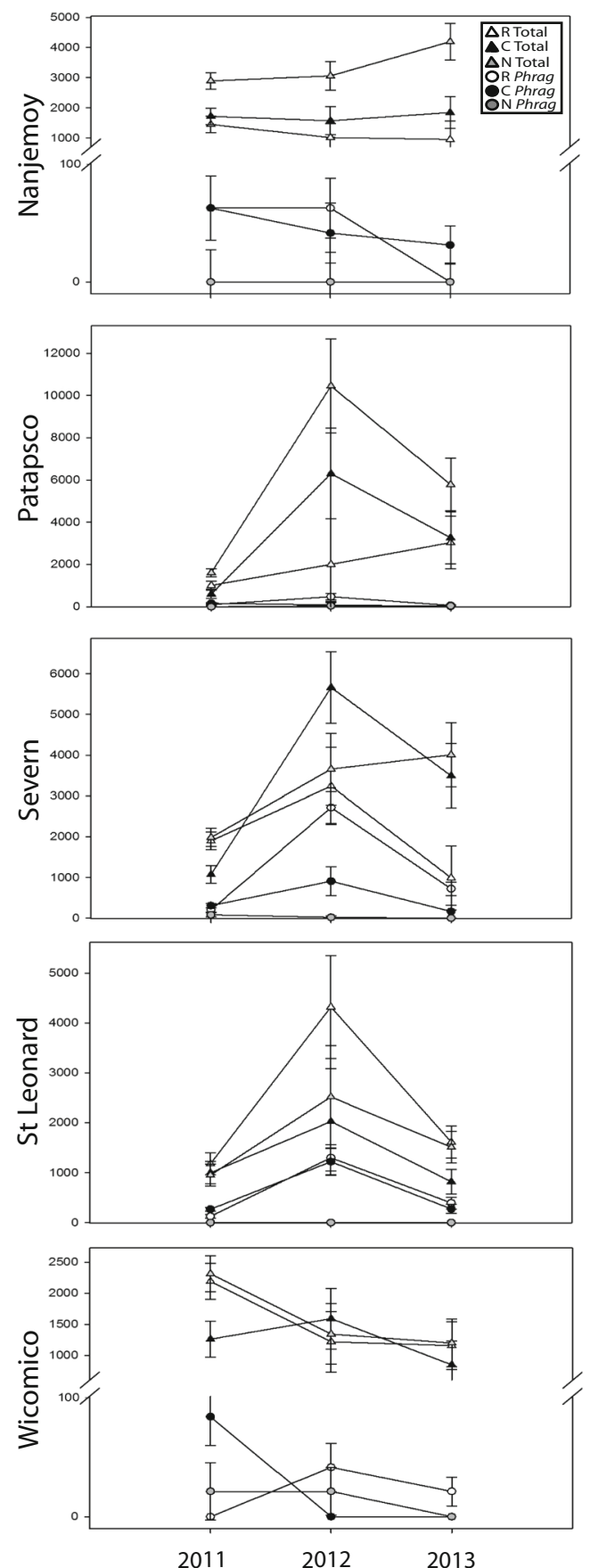

Fig. 5 Proportional germination of Phragmites and total emergence. The five study subestuaries are depicted for both total germination (seedbank density, "Total " in legend) of all species and, and the germination rates of Phragmites ("Phrag" in legend) relative to plots. Values on the Yaxis are total emergence expressed as per $\mathrm{m}^{2} \pm 1 \mathrm{se}$

under Phragmites monocultures, as other studies on the impact of Phragmites' presence and removal on seedbanks have shown (Baldwin et al. 2010; Ailstock et al. 2001; Hallinger and Shisler 2009). The presence of diverse seed banks suggests great promise for passive revegetation in these systems, but below we will address some potential caveats for restoration.
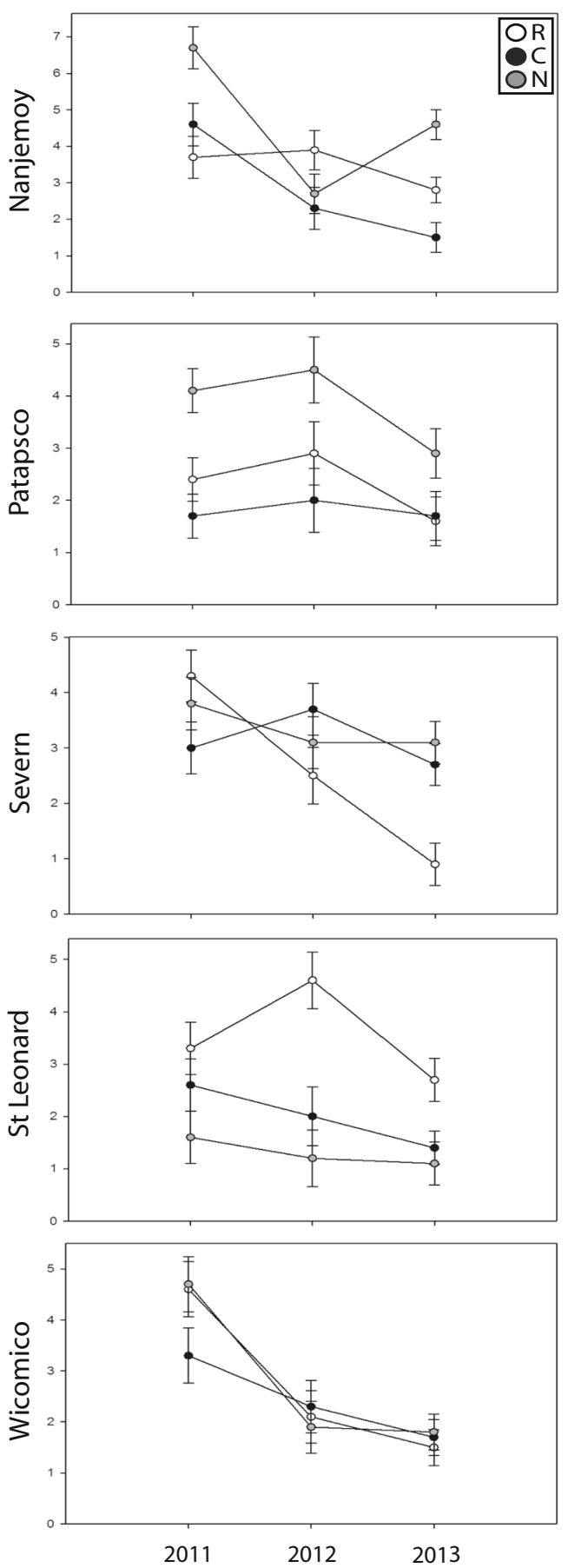

Fig. 6 Impact of Phragmites removal on species richness. Mean species richness across the five subestuaries over time and cover type (" $\mathrm{C}$ " control, "R" removal, "N" native). Values on the $Y$ axis are total emergence expressed as per $\mathrm{m}^{2} \pm 1 \mathrm{se}$

\section{The Effects of Herbicide and Vegetation Type on Seedbank Density and Emergence (Question 1)}

We were interested in whether the plots had sufficient seedbank density and richness to drive passive revegetation, both in richness and quantity. In Chesapeake Bay, Phragmites spread and colonization are predominately 
Table 4 Total germination. All five wetlands are presented to determine treatment effect (Phragmites removed after year 1, Phragmites monoculture intact, native reference plot) impacted total emergence. Results show one-way ANOVA of treatment within the river for each year $(\alpha=0.05)$

Total germination

\begin{tabular}{|c|c|c|c|c|c|c|}
\hline & \multicolumn{2}{|c|}{ Year 1} & \multicolumn{2}{|c|}{ Year 2} & \multicolumn{2}{|c|}{ Year 3} \\
\hline & $\mathrm{F}$ & $\mathrm{P}$ & $\mathrm{F}$ & $\mathrm{P}$ & $\mathrm{F}$ & $\mathrm{P}$ \\
\hline Nanjemoy & 7.79 & 0.0013 & 5.03 & 0.0110 & 7.59 & 0.0014 \\
\hline Patapsco & 7.13 & 0.0020 & 3.73 & 0.0324 & 1.52 & 0.2306 \\
\hline Severn & 5.13 & 0.0101 & 2.08 & 0.1385 & 4.16 & 0.0225 \\
\hline St Leonard & 0.30 & 0.7401 & 1.35 & 0.2705 & 2.47 & 0.0942 \\
\hline Wicomico & 4.02 & 0.0253 & 0.15 & 0.8602 & 0.25 & 0.7797 \\
\hline
\end{tabular}

the result of seed transport (McCormick et al. 2010a; McCormick et al. 2010b; Kettenring et al. 2010), so the prevalence of viable Phragmites seeds in seedbanks following removal would likely counter revegetation and restoration efforts. Phragmites was a major component of the overall seedbank composition in two of the subestuaries, which suggests that passive revegetation efforts are unlikely to be successful in those locales.

Species richness of the seedbanks did not seem to be impacted by herbicide treatment, but was frequently greater in the native plots. Contrary to prior conclusions that species richness decreases under plant invasions (Gioria et al. 2014), only samples from the Patapsco had consistently higher species richness at the native site compared to the two Phragmites sites. In the other subestuaries, richness varied with time and was similar in the control and reference plots. While counterintuitive, the low richness values were likely related to the vegetation composition in the St Leonard native plot, which was a community of two species-S. alterniflora and A. cannabina.

\section{Relationships between Seedbank Composition and Vegetation Cover Types (Question 2)}

Wetland seedbanks can be highly variable even at small spatial scales and under the same vegetation types (Huiskes et al. 1995). Seedbank composition was highly variable within and among the subestuaries in our study and did not reflect the vegetation cover type. Rather, we found variation across the subestuary that could have been the result of the unique physical conditions of each plot and subestuary. Seedbank composition is typically not related to above ground vegetation, and will follow sitespecific physical conditions (Elsey-Quirk and Leck 2015).

It is likely that the spatial variation in seedbanks prior to treatment was broad enough to account for the differences between the control and removal plots, which were both Phragmites monocultures prior to herbicide treatment, in several of the subestuaries. Site history and prior disturbance can alter tidal flow across wetlands and change seed dispersal patterns (Elsey-Quirk and Leck 2015). In the Nanjemoy, the two Phragmites-dominated plots were separated by an historic road that could alter how the seeds mixed on the tides and may have driven large spatial variability in seedbanks. The Patapsco plots were in discontinuous "pocket wetlands" where the mixing of local seed sources was likely only during larger tidal events. The pretreatment seedbank composition in the Severn River showed variation between the Phragmites monocultures as well. Here, too, there were physical characteristics that could alter how tides flood the plots - a large dike and pier separate the two Phragmites plots from each other. Since the seedbanks show strong dissimilarity within the plots, we believe that the physical structure and topography of the wetland likely had more impact on seedbank composition than the cover type. Even a small pier, like the one on the St Leonard River that separates the control and removal plots, could explain the significant differences in seedbank composition between Phragmites monocultures. The control and removal plots on the Wicomico are the only ones in the study that did not have a significant pairwise difference in the seedbank composition, likely because the Wicomico subestuary site was a large continuous wetland with the most fetch of any in the study. The fetch may contribute to mixing the seedbank and has been found to impact seedbank composition elsewhere (Baldwin et al. 2010).

Seedbank composition, density, and diversity can also vary across tidal wetlands at the landscape (subestuary) scale (Elsey-Quirk and Leck 2015; Pederson and Baldwin 2004). In tidal systems, seed transport is dictated by tide flow more than wind or seed rain, and variation of the wetland surface can alter how seeds are dispersed (Hopfensperger et al. 2009; Huiskes et al. 1995). Within the subestuary, physical factors such as fetch can impact seedbank composition between sites, and some down-wind areas will receive heavier propagule loads (Baldwin et al. 2010). On a smaller scale, seeds sort based on size in tidal systems (Leck 1989). In individual wetlands, fragmentation and debris can also alter the seedbanks (Hopfensperger et al. 2009). In tidal salt wetlands, seedbank composition will discriminate between discrete salinity zones, where the seeds are most likely to survive to establishment (Unger 2001). Spatial and temporal variation in tidal systems made interpretation of results especially complex (Hopfensperger et al. 2009; Leck 1989). It is also conceivable that dense vegetation, such as Phragmites monocultures, could promote flocculation of seeds. Given all of the impacts of tide and topography on seedbank composition, we believe that the physical characteristics of a wetland impact the species composition more than local seed rain or cover vegetation. 


\section{The Impact of Phragmites Removal on Seedbank Composition (Question 3)}

We found enough natural variability in tidal wetland seedbanks to necessitate site-specific answers. In two of our sites, the Patapsco and the Severn, seedbanks in the removal plots were less similar to the control and reference plots in years 2012 and 2013 than prior to spraying. In these two subestuaries, the removal seedbank was less similar to the reference and control than the latter were to each other. It appears that removing Phragmites may result in a novel seedbank composition in some cases, and not a convergence on the native reference state, nor a return to the composition of a Phragmites-dominated wetland. For example, the control and removal seedbank composition in the Nanjemoy converged after herbicide application. This result was not expected, especially because the composition of the reference plot was still significantly different from the other two. It is unclear whether the changes in composition could be attributed to the herbicide treatment, or if there was another factor affecting seedbank composition. While some herbicides can impact the seedbank for several years post spraying, this is not commonly the case with glyphosate (see review in Hazelton et al.).

Seedbank composition frequently varies at multiple temporal scales. On a multi-year time-scale, seedbanks change with time from a disturbance or invasion as the persistent native seedbank exhausts itself and undesirable propagules accumulate (Van der Valk and Pederson 1989). Conversely, following restoration, the native seedbank will accumulate with time until it is a viable propagation source (Neff et al. 2009). Episodic or stochastic flooding events can change composition from year to year (Leck 1989). Even within a year, the seedbank composition will vary by season to a degree that management efforts can be timed with desired germination (Morazia-Luna and Zedler 2007). It is likely that three of the subestuaries' seedbanks (Patapsco, Severn, and St. Leonard) were undergoing temporal variation in seedbank composition, and more research on Phragmites invasion is justified to determine the site specific factors driving the variation we documented.

\section{Functional Diversity in Seedbanks: Implications for Restoration (Question 4)}

Functional diversity (Byun et al. 2013; Gioria et al. 2014) and "ecological redundancy" (Suding 2011) contribute to the resilience of a wetland and its ability to resist invasion. We sought to determine if the functional diversity in the seedbanks could justify passive revegetation. We approached this question from two angles: diversity in structural form (the functional types: forb, graminoid, woody) and diversity in life history (guild: annual, perennial, differentiated by native or introduced status). We found that the functional compositions of the seedbanks vary greatly between subestuaries, yet are relatively consistent between plots in a subestuary. Stability of functional composition over the study area and duration was notably different from the seedbank species composition; the seedbank composition varied with time and space.

The relative contribution of the three guilds to seedbank composition was more varied than the functional groups. Each subestuary had some introduced perennial seedbank component in all plots. High introduced perennial germination is likely due two factors: the presence of Phragmites in the control plot and the prevalence of Acorus spp. and Typha spp. in the reference plot.

Woody species were a very minor component of all of the seedbanks in all of the subestuaries. While low emergence of woody vegetation is well-documented in wetland seedbanks (Leck 1989), they are a major component of the aboveground vegetation in our study (unpublished data). The woody species Iva frusctescens, Baccharis halmifolia, Hibiscus moscheutos, and Kostyletskia virginica were often the dominant cover in Chesapeake Bay brackish wetlands (McCormick and Somes 1982 and unpublished tidal wetland maps associated with the report). Across years, the St Leonard control had a higher woody component than the other Chesapeake Bay wetlands studied, which is more an artifact of the forested upland border than abundant woody wetland species. Predictably, native annual forbs were a consistent component to the seedbank and were dominated in all sites by Pluchea odorata, and A. cannabina. In the third year, there was potentially a mast year of Symphotrichum subulatum, which appeared in large numbers in the seedbank. Graminoids were the dominant native perennials, particularly Spartina patens, S. alterniflora, Schoenoplectus acutus, and Panicum virginica.

Taken together, it is evident that there were functionally diverse seedbanks under each of the vegetation types and in each plot within the subestuaries. Subestuaries like the Nanjemoy, which had higher germination rates of native and annual perennials, in principal should have had a higher likelihood of vegetation recovering from passive revegetation. The native plot at the Nanjemoy wetland had a very high diversity of both forbs and graminoids, with $>100$ total species detected in the seedbank and vegetation (EH unpublished findings).

\section{Restoration Potential of Brackish Wetlands Following Phragmites Removal}

In wetland management and restoration, the seedbank composition can offer insight into the potential for and process of wetland recovery (Van der Valk and Pederson 1989; Brown 1998; Neff et al. 2009). However, as is the case with this and other studies, seedbank composition does not always predict the aboveground vegetation (Brown 1998; Gioria and Pysek 
2016; Gioria et al. 2014; Hopfensperger et al. 2009; Hopfensperger 2007). The theory of self-designed wetlands appeals to many restoration practitioners because of potential to maintain local vegetation compositions and genetic stocks and keep costs low (Leck 2003; Van der Valk and Pederson 1989; Mitsch and Wilson 1996). However, despite benefits of passive revegetation, it may not be appropriate in many Phragmites-invaded wetlands because of low recovery potential in the seedbanks of old invasions where native species have been replaced by undesirable species (Wilcok 2012; Frieswyk and Zedler 2006; Van der Valk and Pederson 1989; Bakker et al. 1996). A low functional diversity in the potential species composition is particularly common in coastal and riparian restorations (Gioria et al. 2014). Additionally, the species that emerge first from any seedbank can be weedy, undesirable, or non-native species, thus restorations relying on soil seedbanks for revegetation should exercise caution (Ficken and Menges 2013; Frieswyk and Zedler 2006). Finally, restored aboveground vegetation does not always reflect the full seedbank composition due to environmental filters that impact germination and recruitment (Gioria and Pysek 2016; Brown 1998; "environmental sieve" Van der Valk 1981). Our results showed that in most cases, there was a functionally diverse seedbank both under Phragmites monocultures and where the invasive vegetation was removed. Wetland restorations where the persistent seedbank has become exhausted require more active revegetation methods (Bakker et al. 1996; Morzaia-Luna and Zedler 2007), but even where seedbanks persist the environmental pressure created by flooding, shading, and other limitations on emergence may preclude reliance on self-design.

Generally, the native reference plots had higher overall germination, more native plants in the seedbank, and fewer invasive plants emerging. This finding emphasizes the need for intact native wetlands in the vicinity of management efforts. Without the native propagule source, passive revegetation will be unlikely. Species richness often declines under invaded canopies, and the subsequent loss of richness decreases the recovery potential of the invaded site (Gioria et al. 2014). We had similar findings in some of the subestuaries. The richness values varied with time, and in the case of the St Leonard, the native plot had a very low species richness that coincided with the reference community. Invaded sites typically had higher counts of invasive propagules than native, while in many cases, native vegetation had higher overall emergence. This major finding was in agreement with a review of seedbanks and invasions by Gioria et al. (2014).

\section{Conclusions}

Our finding that there were functionally diverse native seedbanks under Phragmites monocultures that persisted after removal has important implications for managers who do not have the ability or budget to actively revegetate after Phragmites removal (sensu Hallinger and Shisler 2009). Specifically, this functional diversity is critical to creating a plant community that was resistant to preventing future Phragmites invasion (Byun et al. 2013); by filling as many niches as possible, managers can quickly reestablish plant communities (resiliency) that are more likely to resist invasions. In some subestuaries, a functionally diverse seedbank under Phragmites monocultures could serve as a propagule source for passive revegetation within the context of selfdesign (sensu Mitsch and Wilson 1996). This self-design potential is particularly true in subestuaries that have high cover of native wetland communities and where Phragmites germination was lower. Additionally, site connectivity played a strong role in the evenness of seedbank composition. Based on these observations, we offer managers a strong caveat: there are numerous invasive propagules in each vegetation type, and a wetland will vary in its capacity to recruit native vegetation based, in part, on barriers to seed dispersal. Site selection is critical for passive revegetation, and it should only be considered as a single component to an adaptive framework that involves continuous monitoring and method adjustments.

Acknowledgements The authors would like to thank Eliza K McFarland and Christine B Rohal for conceptual support; and Jay O’Neill, Jenna Malek, and Andrew Keppel for field assistance. Susan Durham provided critical statistical support. We are grateful that Alec Hay provided greenhouse support throughout the study. The editors of Estuaries and Coasts and the external reviewers provided thoughtful and valuable advice, and this manuscript benefitted hugely from their input and suggestions. This work was supported by the National Oceanic and Atmospheric Administration (NOAA) Center for Sponsored Coastal Ocean Research (CSCOR) award number NA09NOS4780214. ELGH was funded in part by a Smithsonian Pre-doctoral Fellowship, a Delta Waterfowl Scholarship, Utah State University Ecology Center, USU Quinney College of Natural Resources, USU Department of Watershed Sciences, and the Society for Wetland Scientists.

Open Access This article is distributed under the terms of the Creative Commons Attribution 4.0 International License (http://creativecommons. org/licences/by/4.0/), which permits use, duplication, adaptation, distribution and reproduction in any medium or format, as long as you give appropriate credit to the original author(s) and the source, provide a link to Creative Commons license and indicate if changes were made.

\section{References}

Ailstock, M.S., C.M. Norman, and P.J. Bushmann. 2001. Common reed Phragmites australis: Control and effects upon biodiversity in freshwater nontidal wetlands. Restoration Ecology 9 (1): 49-59.

Bakker, J.P., P. Poschlod, R.J. Strykstra, R.M. Bekker, and K. Thompson. 1996. Seedbanks and seed dispersal: Important topics in restoration 
ecology. Acta Botanica Neerlandica 45 (4): 461-490.

Baldwin, A.H., M.S. Egnotovich, and E. Clarke. 2001. Hydrologic change and vegetation of tidal freshwater marshes: Field, greenhouse, and seed-bank experiments. Wetlands 21 (4): 519-531.

Baldwin, A.H., K.M. Kettenring, and D.F. Whigham. 2010. Seedbanks of Phragmites australis-dominated brackish wetlands: Relationships to seed viability, inundation, and land cover. Aquatic Botany 93 (3): 163-169.

Brown, S.C. 1998. Remnant seedbanks and vegetation as predictors of restored marsh vegetation. Canadian Journal of Botany 76 (4): 620 629.

Byun, C., S. Blois, and J. Brisson. 2013. Plant functional group identity and diversity determine biotic resistance to invasion by an exotic grass. Journal of Ecology 101 (1): 128-139.

Chambers, R.M., L.A. Meyerson, and K. Saltonstall. 1999. Expansion of Phragmites australis into tidal wetlands of North America. Aquatic Botany 64 (3): 261-273.

D'Antonio, C., and L.A. Meyerson. 2002. Exotic plant species as problems and solutions in ecological restoration: A synthesis. Restoration Ecology 10 (4): 703-713.

Elsey-Quirk, T., and M.A. Leck. 2015. Patterns of seedbank and vegetation diversity along a tidal freshwater river. American Journal of Botany 102 (12): 1996-2012.

Ficken, C.D., and E. Menges. 2013. Seasonal wetlands on the Lake Wales Ridge, Florida: Does a relict seedbank persist despite long term disturbance? Wetlands Ecology and Management 21 (6): 373-385.

Frieswyk, C.B., and J.B. Zedler. 2006. Do seedbanks confer resilience to coastal wetlands invaded by Typha× glauca? Botany 84 (12): 1882 1893.

Gioria, M., and P. Pyšek. 2016. The legacy of plant invasions: Changes in the soil seedbank of invaded plant communities. Bioscience 66 (1): $40-53$.

Gioria, M., V. Jarošík, and P. Pyšek. 2014. Impact of invasions by alien plants on soil seedbank communities: Emerging patterns. Perspectives in Plant Ecology, Evolution and Systematics 16 (3): 132-142.

Gioria, M., and B. Osborne. 2009. Assessing the impact of plant invasions on soil seedbank. Vegetation Science 20 (3): 547-556.

Hallinger, K.D., and J.K. Shisler. 2009. Seedbank colonization in tidal wetlands following Phragmites control (New Jersey). Ecological Restoration 27 (1): 16-18.

Hazelton, E. L. G., T. J. Mozdzer, D. M. Burdick, K. M. Kettenring, and D. F. Whigham. 2014. "Phragmites australis management in the United States: 40 years of methods and outcomes." AoB plants 6: https://doi.org/10.1093/aobpla/plu001.

Hopfensperger, K.N. 2007. A review of similarity between seedbank and standing vegetation across ecosystems. Oikos 116 (9): 1438-1448.

Hopfensperger, K.N., K.A.M. Engelhardt, and T.R. Lookingbill. 2009. Vegetation and seedbank dynamics in a tidal freshwater marsh. Journal of Vegetation Science 20 (4): 767-778.

Huiskes, A.H.L., B.P. Koutstaal, P.M.J. Herman, W.G. Beeftink, M.M. Markusse, and W. De Munck. 1995. Seed dispersal of halophytes in tidal salt marshes. Journal of Ecology 83 (4): 559-567.

Kettenring, K. M., S. de Blois, and D. P. Hauber. 2012. Moving from a regional to a continental perspective of Phragmites australis invasion in North America. AoB plants 2012:pls040.

Kettenring, K.M., and S.M. Galatowitsch. 2011. Seed rain of restored and natural prairie wetlands. Wetlands 31 (2): 283-294.

Kettenring, K.M., and C. Reinhardt Adams. 2011. Lessons learned from invasive plant control experiments: A systematic review and metaanalysis. Journal of Applied Ecology 48 (4): 970-979.

Kettenring, K.M., M.K. McCormick, H.M. Baron, and D.F. Whigham. 2010. Mechanisms of Phragmites australis invasion: Feedbacks among genetic diversity, nutrients, and sexual reproduction. Journal of Applied Ecology 48: 1305-1313.
King, R.S., W.V. DeLuca, D.F. Whigham, and P.P. Marra. 2007. Threshold effects of coastal urbanization on Phragmites australis (common reed) abundance and foliar nitrogen in Chesapeake Bay. Estuaries and Coasts 30: 469-481.

La Peyre, M.K., C.S. Bush Thom, C. Winslow, A. Caldwell, and J.A. Nyman. 2005. Comparison of seed bank size and composition in fringing, restored, and impounded marsh in southwest Louisiana. Southeastern Naturalist 4 (2): 273-286.

Leck, M.A. 2003. Seed-bank and vegetation development in a created tidal freshwater wetland on the Delaware River, Trenton, New Jersey, USA. Wetlands 23 (2): 310-343.

Leck M.A. 1989. "Wetland Seedbanks.” In Leck, M. A. (Ed.). 2012. Ecology of soil seedbanks. Elsevier.

Legendre, P., and L. F. Legendre (2012). "Numerical ecology" (Vol. 24). Elsevier.

Mack, R.N., D. Simberloff, W. Mark Lonsdale, H. Evans, M. Clout, and F.A. Bazzaz. 2000. Biotic invasions: causes, epidemiology, global consequences, and control. Ecological Applications 10 (3): 689710 .

McCormick, M.K., K.M. Kettenring, H.M. Baron, and D.F. Whigham. 2010a. Spread of invasive Phragmites australis in estuaries with differing degrees of development: Genetic patterns, Allee effects and interpretation. Journal of Ecology 98: 1369-1378.

McCormick, M.K., K.M. Kettenring, H.M. Baron, and D.F. Whigham. 2010b. Extent and reproductive mechanisms of Phragmites australis spread in brackish wetlands in Chesapeake Bay, Maryland (USA). Wetlands 30: 67-74.

McCormick, J., J.A. Somes Jr. 1982. "Coastal Wetlands of Maryland." Maryland Department of Natural Resources, Annapolis, MD.

Mitsch, W.J., and R.F. Wilson. 1996. Improving the success of wetland creation and restoration with know-how, time, and self-design. Ecological Applications 6 (1): 77-83.

Morzaria-Luna, H.N., and J.B. Zedler. 2007. Does seed availability limit plant establishment during salt marsh restoration? Estuaries and Coasts 30 (1): 12-25.

Neff, K.P., K. Rusello, and A.H. Baldwin. 2009. Rapid seedbank development in restored tidal freshwater wetlands. Restoration Ecology 17 (4): 539-548.

Palmer, M.A. 2009. Reforming watershed restoration: Science in need of application and applications in need of science. Estuaries and Coasts 32: 1-17.

Peter, C.R., and D.M. Burdick. 2010. Can plant competition and diversity reduce the growth and survival of exotic Phragmites australis invading a tidal marsh? Estuaries and Coasts 33 (5): 1225-1236.

Peterson, J.E., and A.H. Baldwin. 2004. Seedling emergence from seedbanks of tidal freshwater wetlands: Response to inundation and sedimentation. Aquatic Botany 78 (3): 243-254.

Poiani, K.A., and W.C. Johnson. 1988. Evaluation of the emergence method in estimating seedbank composition of prairie wetlands. Aquatic Botany 32 (1-2): 91-97.

Saltonstall, K. 2002. Cryptic invasion by a non-native genotype of the common reed, Phragmites australis, into North America. Proceedings of the National Academy of Sciences 99 (4): 24452449.

Sciance, B., C.J., Patrick, D.E., Weller, M.N., Williams, M., McCormick, and E.L.G. Hazelton 2016. Local and regional landscape factors associated with the invasion of Chesapeake Bay marshes by the common reed Phragmites australis. Biological Invasions 18 (9): 2661-2677.

Sellner, K.G., S.G. Sellner, R.V. Lacouture, and R.E. Magnien. 2001. Excessive nutrients select for dinoflagellates in the stratified Patapsco River estuary: Margalef reigns. Marine Ecology Progress Series 220: 93-102. 
Suding, K.N. 2011. Toward an era of restoration in ecology: Successes, failures, and opportunities ahead. Annual Review of Ecology, Evolution, and Systematics 42 (1): 465.

Ungar, I.A. 2001. Seedbanks and seed population dynamics of halophytes. Wetlands Ecology and Management 9 (6): 499-510.

USDA-NRCS. 2015. http://plants.usda.gov/. Last accessed September 2015.

Van der Valk, A.G. 1981. Succession in wetlands: A gleasonian approach. Ecology 62 (3): 688-696.

Van der Valk AG, and R. L. Pederson. 1989. "Seedbanks and the Management and Restoration of Natural Vegetation." In Leck, M. A. (Ed.). (2012). Ecology of soil seedbanks. Elsevier.
Wetzel, P.R., A.G. van der Valk, and L.A. Toth. 2001. Restoration of wetland vegetation on the Kissimmee River floodplain: Potential role of seedbanks. Wetlands 21 (2): 189-198.

Wilcox, D.A. 2012. Response of wetland vegetation to the post-1986 decrease in Lake St. Clair water levels: Seed-bank emergence and beginnings of the Phragmites australis invasion. Journal of Great Lakes Research 38 (2): 270-277.

William, J. M., and S. E. Jorgensen. "Ecological engineering and ecosystem restoration." (2003): 1-22.

Zedler, J.B., and S. Kercher. 2005. Wetland resources: Status, trends, ecosystem services, and restorability. Annual Review of Environment and Resources 30: 39-74. 